\title{
2008 Global Financial Recession Impact on Yemen's Economy and Oil Industry
}

\author{
Abdulghani Gaghman \\ The Bucharest University of Economic Studies, Romania \\ abdulghanigaghman@stud.ase.ro
}

\begin{abstract}
Yemen as an oil exporting country with relatively larger populations and modest oil re-sources has witnessed a sharp deterioration in their public finances and current account balances in 2008-2009, as a result of financial crisis mainly lower oil prices leading to a weakening of the economy. This study targeting the global crisis impact on Yemen's economy, by analysis the macroe-conomic indicators to understand how much the government achieve in term of economic effi-ciency which reflected in economic growth, full employment, trade balance and price stability. Yemen has less developed monetary banking system and relatively minor exposure to for-eign banks, which result in fair impact from the financial global crisis. However, the government can't sustain exchange rate and stabilize the price the non-oil declined by $3 \%$ of the determined gross domestic product (GDP) in 2009 , from $6.98 \%$ in 2008 . This paper found that the crisis has negative impact on the government revenues, trade bal-ance and significant reduction in foreign direct investment (FDI), caused reduction in spending and widened the deficits in the budget and the balance of payments. Real growth has been achieved relatively high rates and through precisely the crisis. The revenues declined more than $10 \%$ in 2009 and government expenditures reduced with regards to decline in oil revenues and service delivery. The government responses were successful in the monetary policy side, but with lots of blurred in the fiscal policies which was subject for critical discussion and assessment. This paper concluded that to improve the overall Yemen's economy and avoid any unpleasant economic event in the future, government should have a strategic plan to achieve sustain growth rate by diverse outcome resources, support the private sector and encourage investments
\end{abstract}

Keywords. Financial Recession, Oil and Gas, Yemen, Crisis, Economy

\section{Introduction}

The Great Recession of 2008-2009 was considered as a systemic crisis where it was characterize by large changing of GDP, emergency government intervention required. The (USA) banking system had major failures, domestic lending reduced, reduction in export earnings and unemployment rate peaked 10\% (Heady, 2008). According to IMF's World economic statistics, world growth is fall to $0.5 \%$ which considers the lowest rate since World War II.

Most of the advance economics went into a recession and followed by many developing economics countries. The global recession force the government to introduce and implement many fiscal and monetary policies and highlight the importance of macroeconomic and microeconomic research to sustain an economic system. (Claessens, 2010) 
Hossain (2010) found that the economic conditions of the Middle East and North Africa region impacted differently from the countries with limited scarce resources relative to their populations like Yemen and Egypt to the oil rich economies in the Gulf countries (GCC).

Yemen as small oil resource country has an economy dominated by the oil and gas sector, other sectors like agricultural, manufacturing and export services represent a small share of the economy. The oil resources represent $27 \%$ of GDP and $90 \%$ of exports (World Bank, $2009 \mathrm{~g}$ ). The fall in oil prices in 2008 has restrained GDP growth to $4.5 \%$ in 2008 and increased the fiscal deficit by 4\% of GDP (World Bank, 2009a). Moreover, the foreign reserves reduced by $24 \%$ in 2009 (CSO, 2010).

The huge impacts of the global crisis underline the importance of having solid understanding of crisis (Claessens, 2010). The aim of this study is to analysis the Yemen economics starting with Section I by investigate the impact of global crisis on the macroeconomic scale for the entire Yemen's economic system. In Section II focus on the effect of global crisis on Yemen's oil industry using some microeconomic indicators such as Production efficiency, demand and supply, export and import. In Section III list and discuss government responses and the macroeconomic (monetary and fiscal) policies that implemented enrich with discussion, assessment and recommendations to have more stable and stronger economic situation.

\section{Yemen Economic Development}

Yemen is still considered to be one of the Least Developed Countries (LDCs) (World Bank, 2009d). The Yemeni economy is confronting a move away from reliance on oil resources to more diverse resource economy, but in reality there is no clear strategic plan for this transition (Salisbury, 2011).

There are several economical challenges for the country such as rapid population growth and reduction in oil production and slow economic diversification (MOIT and MOM). Yemen has less developed monetary banking system and relatively minor exposure to foreign banks, which result in fair impact from the financial global crisis (CBY, 2009). Nevertheless, Yemen remains exposed to real shocks such as depleting oil resources, lower foreign investment, and lower remittances. Other indicators show that unemployment rates have risen to $26 \%$ in 2012, with the highest population growth rate in the world (Breisinger et al, 2011). The poverty ratio increase from $41 \%$ in 2009, to 54.4\% in 2012. (World Bank, 2007 and 2012)

\section{Macroeconomic Indicators}

Macroeconomic is dealing with the large market system scale where it classified to Fiscal and monetary policies like the interest rate, trade balance and investment (Claessens, 2010). Macroeconomics indicators are used to measure how well an economy performed, how it works and how the performance can be improved. The basic goal is to achieve economic growth, full employment, price stability, trade balance and economic efficiency.

The Yemen government used the expenditure approach to calculate the total value of economic activities which referred to as Gross Domestic Product (GDP). Schiller (2011) determined the GDP based on (AD-AS) model.

In this paper we will focus on the component as Aggregate demand $\mathrm{AD}$ as part of the Basic Circular Flow concept, where Keynes pointed that AD has a strong influence on the economy output specially in the short term or during recessions (Keynes, 2006),

\section{Aggregate Demand (AD) $=\mathbf{C}+\mathbf{I}+\mathbf{G}+($ Net Export)}


Where: (G) Government expenditures, (C) Consumer expenditures and (I) Investment and Trade balance (Export- Import) (Schiller, 2011).

The shift of the aggregate demand curve has direct impact on the equilibrium level of real GDP to be below/above the full-employment level (assuming the Aggregate Supply stable in long-run equilibrium). To avoid recession the $\mathrm{AD}$ curve must shift right or increase. Dutt (2006) highlighted that $\mathrm{AD}$ parameters give a strong overview of the macroeconomic framework also it has impact on the long term equilibrium growth rate (Krishna, 2005).

Figure 1: The AD curve shows that the left shift will have negative impact on the real GDP (Source: Economic Online UK)

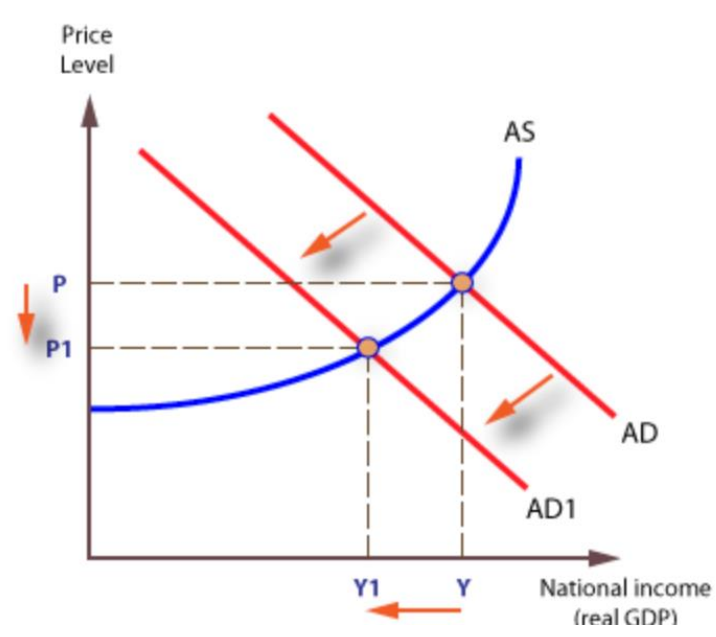

\section{Gross Domestic Production (GDP)}

GDP is one of the most significant indicator to measure the country economic performance, Based on Yemen's Central Statistics Organization (CSO) data, real growth in the national economy strengthened from $4.5 \%$ in 2008 and $5.8 \%$ in 2009 to $7.1 \%$ in 2010, while the real output (GDP at constant price) decreased from $20.5 \%$ in 2008 to $-6.1 \%$ in 2009 after that it has been improved to $18.04 \%$ in 2010 . The 2011 reduction in Real GDP to $-14 \%$ due political instability in the country see figure (2).

\section{Inflation Rate}

As a result of global financial crisis, the rapid shrinkage in oil revenues coupled with the decline in growth rate and production have a direct impact on the monetary situation and cause macroeconomic instability and impact the inflation ratio (Frisch, 1983 and Schiller, 2011).

Inflation, as measured by the USA and the World Bank by using Consumer Price Index (CPI) (Schiller, 2011), reduced form 19\% in 2008 to 5.4\% in 2009. This figure improved to $11.2 \%$ in 2010 . However, CPI is not the perfect measure of inflation, where it just monitor the price over time and CPI unlike inflation, measured based on a fixed basket of services and goods (market basket) (Schiller 2011).

GDP deflator is a price measurement tool considering the change of people's consumption and investment pattern, including the services and goods at the local or government level (Schiller, 2011). In Yemen GDP deflator use to convert the GDP at constant price to real GDP, which reduced significantly from $15.38 \%$ of GDP in 2008 to $-9.87 \%$ of GDP in 2009 and rise to 10.34 in 2010 see figure (2).

Yemen economy has a vulnerable situation in the term of political, social and security reasons, on the public expenditure side, the government aims to avoid cutting or limit the budget, which resulted in expanding fiscal policy and force the price to rise. As a result, the government failed to achieve price stability where the inflation rate changed more than $3 \%$ in the period of 2006-2010. (MOIT). 


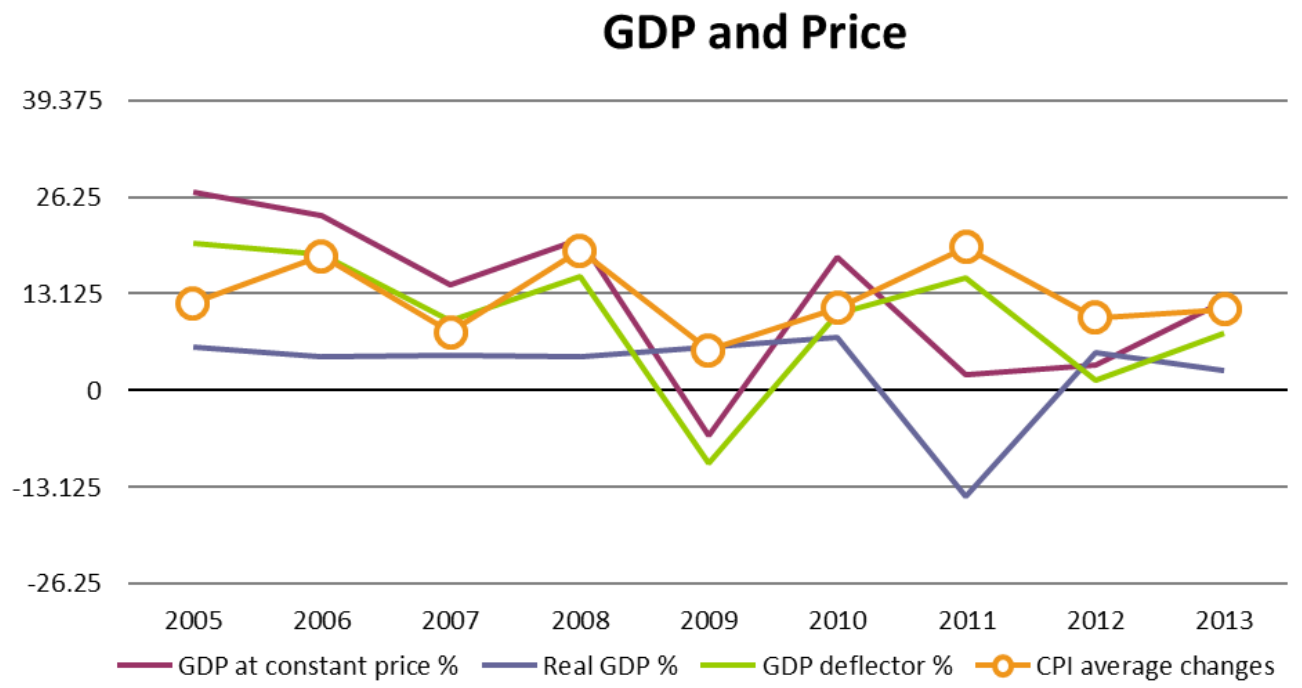

Figure 2. GDP main indicators and prices for the period (2005-2013), shows that the GDP at constant price fall sharply in 2009 due to GDP deflator reduction, and the real GDP not affected in 2009 by the crisis (Source: CSO)

\section{Government Finance}

Yemen affected by a decline in world oil prices and oil revenues declined, resulting in a lower surplus in the general budget and the deterioration of the deficit (MOF). Public revenues decreased from $32.1 \%$ of GDP in 2008 to $22.9 \%$ of GD in 2009 due to lower oil and gas revenues, The revenue increased to $26.9 \%$ in 2010 , basically due to higher oil and gas revenues. Public expenditure also decreased from $35.8 \%$ of GDP in 2008 to $30.7 \%$ in 2009 , due to the fall expenditures (current and development) by $4.8 \%$ and $4.7 \%$ respectively. These deterioration cause shift the aggregate demand curve to the left. The local banking sector in the country has limited risk to the crisis in the financial markets (CBY, 2009).

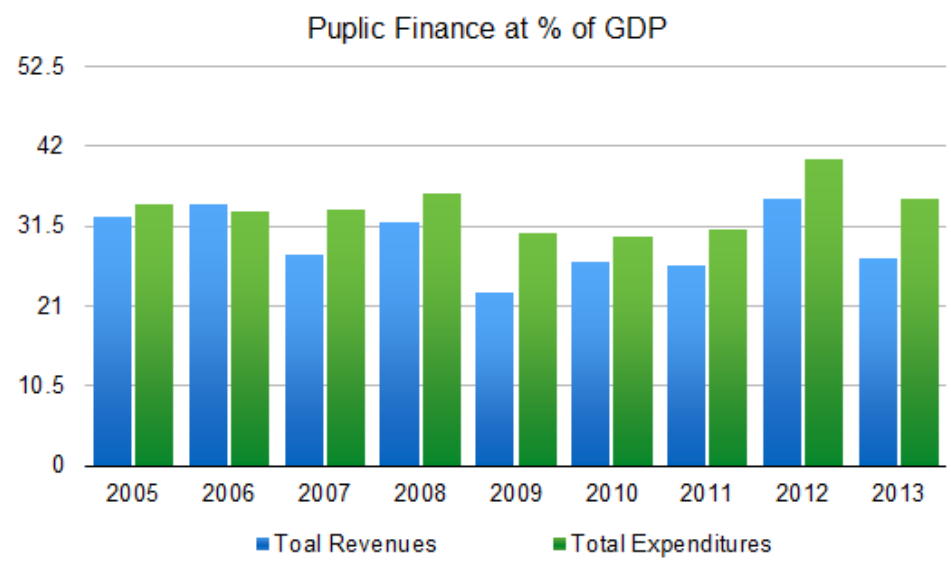

Figure 3: Total Revenues vs Total Expenditures, shows reduction in expenditures associated with reduction in revenues in 2009 (Source: CSO).

The decline in oil revenues give the government no choices either to delay spending or to cut down current spending on future development projects. As a result, the 2009 and 2010 budget faced enormous pressure to meet its commitments in term of current and development expenditures without affecting the current spending on salaries and wages and other strategic recurrent spending items (CBY, 2010). 


\section{Financial Debt}

In 2009, the government's share of oil exports decrease by 32\% compared with 2008 . In 2010 , the share increases slightly by $2 \%$. As a consequence of the above events, external public debt rose from $19 \%$ of GDP in 2008 to $21.6 \%$ in 2009 due to the oil price increase in late 2008. This increment has fall in 2010 to $19.5 \%$ of GDP, while gross domestic public debt continues increased from $27.2 \%, 38.3 \%$ to $38.6 \%$ of GDP during the same period (CBY, 2012).

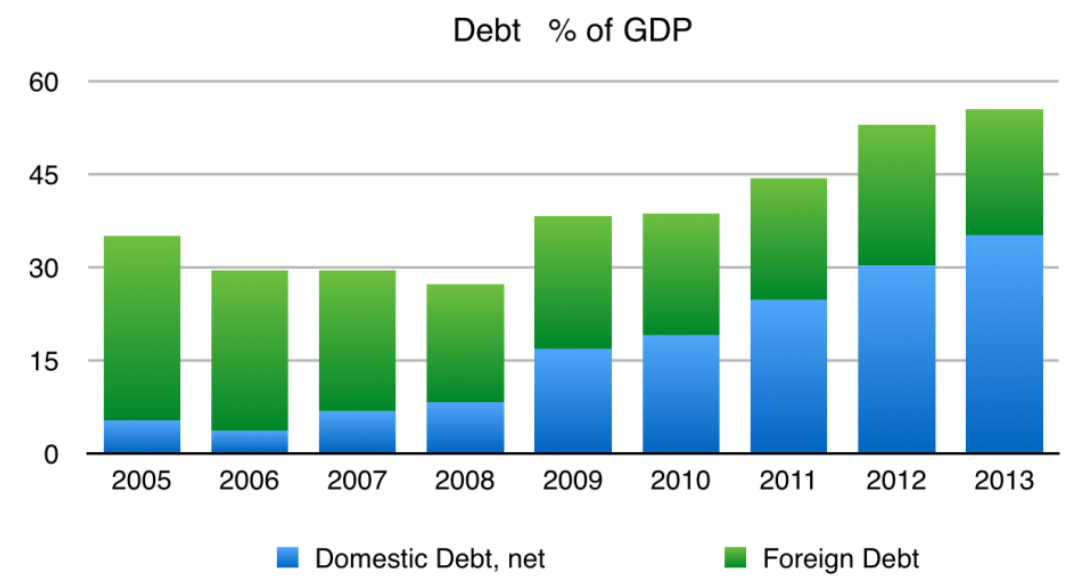

Figure 4: Debt as \% of GDP Trend for the period (2005-2013), shows increase the debt from

\section{Budget Deficit}

2009 due to falling oil output (Source: CSO).

The deficit is an outcome from the global recession and mainly poor macroeconomic strategy, which is the result of government spending more than its revenues, and each year deficit adds to the national debt (Schiller, 2011).

The falling of oil production and increase the demand for commodities from abroad, the government ran successive budget deficits since 2007 as spending overtook income (World Bank, 2008). The deficit can hit the economy in the long term by increase aggregate demand (i.e. Higher deficit in 2009 onward associated with the reduction in investment as shows in figure 7) (Gale, 2003).

The budget deficit increased from $3.7 \%$ of GDP in 2008 to $7.8 \%$ in 2009 due to fall of international oil prices. The lower government oil export revenue, lower the public revenues and cause higher fiscal deficit in 2009. In contrast, increase the oil revenue in 2010 reduced this figure to $3.2 \%$. On the other hand, the spending deficit significantly reduced from $8 \%$ in 2008 to -7.6 in 2009 and $-8.5 \%$ in 2010 due to increase of total debt or borrowed fund used to finance the government expenditures in the same period see figure (5). 


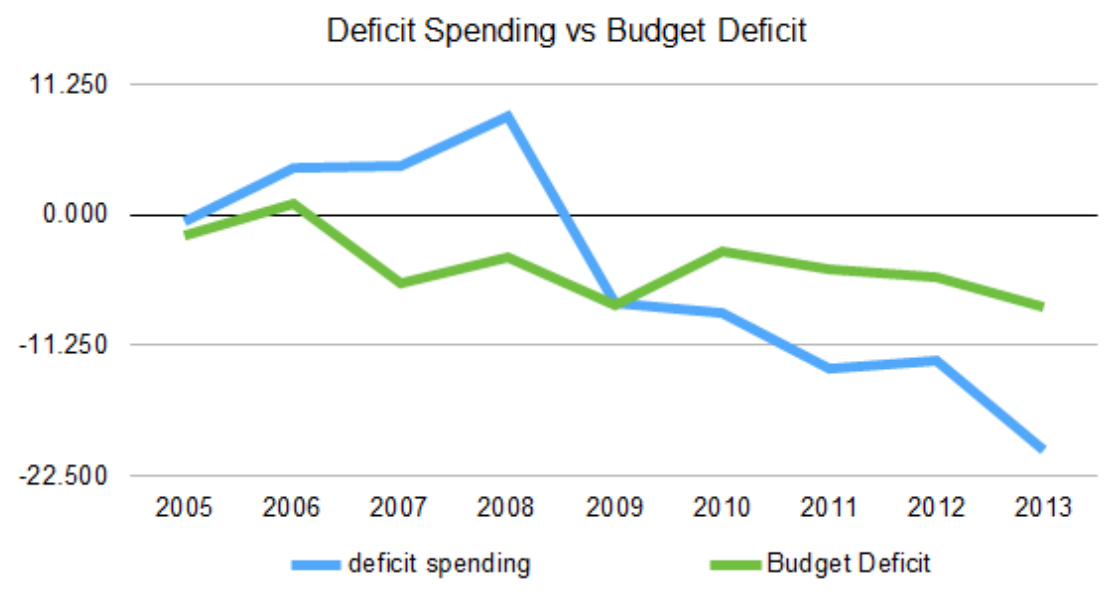

Figure 5: Deficit Spending vs Budget Deficit \% of GDP, shows the budget deficit start from 2007, and spending deficit (in blue) increase due to use more debt to finance government expenditures (Source: CSO).

\section{Unemployment Rate}

People who would like to work, but cannot find a job are not contributing to the economy's production of goods or services. As Schiller (2011) concluded that, to avoid cyclical unemployment, the ratio of growth should be as far as the growth of the labor force. Theoretically, there are certain criteria determine the unemployed labor force, such as not employed or employed for less than 12 hours a week and are available to start in the short period, and have displayed active search effort in the past four weeks (Marshalle, 2006).

\section{GDP vs Unemployment Rate}

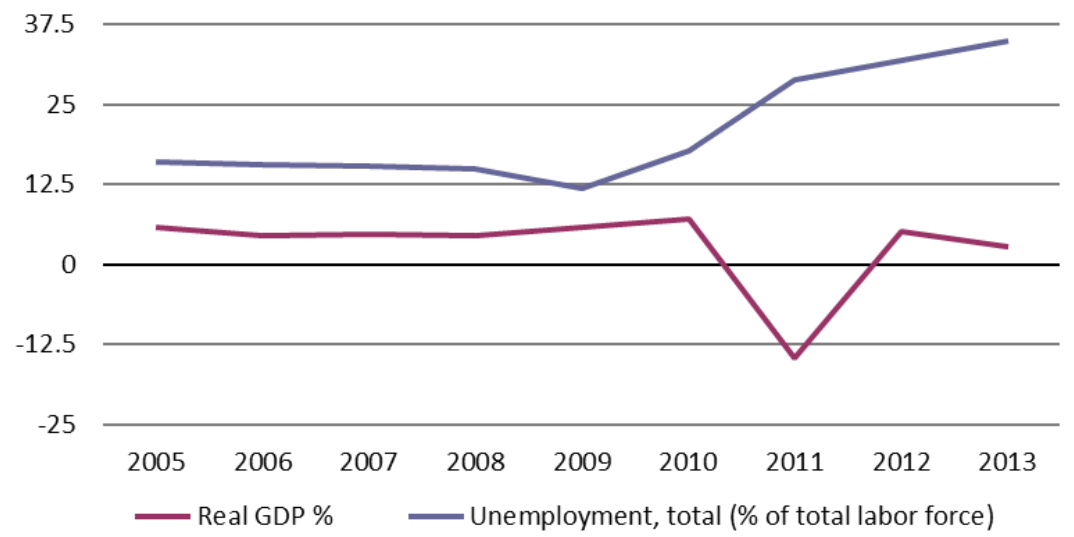

Figure 6: The Unemployment Rate vs Real GDP shows slightly impact of unemployment in 2009 (Source: CSO).

In general insufficient demand during the crisis cannot achieve full employment, but in Yemen the unemployment ratio showed small decrease from 15\% in 2008 to $13 \%$ in 2009 regardless to the global crisis and its consequences. In 2011 ratio jumped to $29 \%$ due to political instability in Yemen as mention earlier.

VII. Foreign Direct Investment (FDI)

Foreign direct investment, net inflows (\% of GDP) in Yemen has been reduced significantly from $5.8 \%$ of GDP to $0.51 \%$ in 2009 , this had affected the development of the 
country by reduce the local productivity growth, and AD decreased (ceteris paribus) (IMF, 2008, 2009, 2010, 2011).

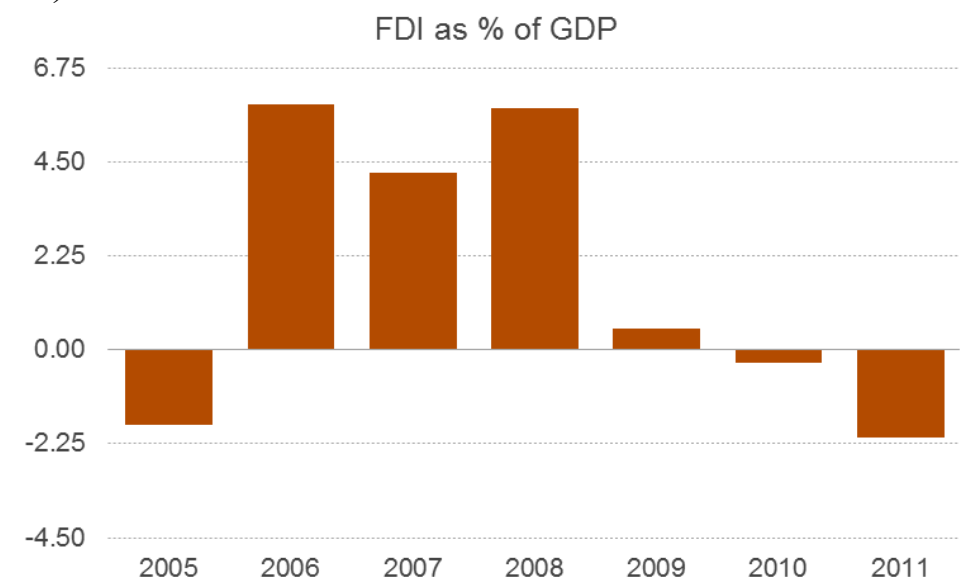

Figure 7: FDI as \% of GDP shows a significant reduction in the investment since 2009. Source: International Monetary Fund (2008-2011)

\section{Impact on Oil and Gas Industry}

Land is one of the scarce productive resources classified beside the labor, capital and entrepreneurial ability. Land generally refers to all natural resources, including wildlife, minerals, water, air, oil and gas (Webster, 2003).

Yemen economy is dominated by production and export of oil, between 2000 and 2009, the oil and gas sector accounted directly for $20-30 \%$ of GDP, $80-90 \%$ of its exports and 70 $80 \%$ of government revenues as Yemen's main source of foreign exchange (Salisbury, 2011).

\section{Total Revenues}

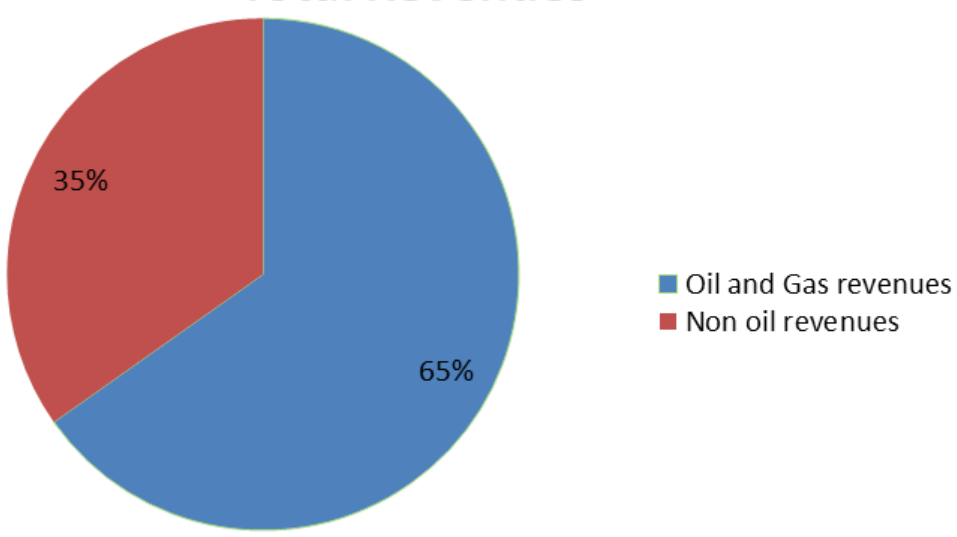

Figure 8: Distribution of Government Revenues \% of GDP shows the oil and gas revenue represent 65\% of total budget revenues for the period (2005-2011) (Source: CSO).

\section{Supply and Demand}

Yemen similar to other oil dependent economic suffers from declining of oil production (from 2007 to 2013 the oil production decrease by 56\%) and the government enjoy exporting easy oil production with a large increase in foreign currency (Dutch Disease) without maturing other industries. In fact, there are other reasons behind this, for instance, the domestic industry is less mature, weak investment environment and political instability (IMF, 2009a). 


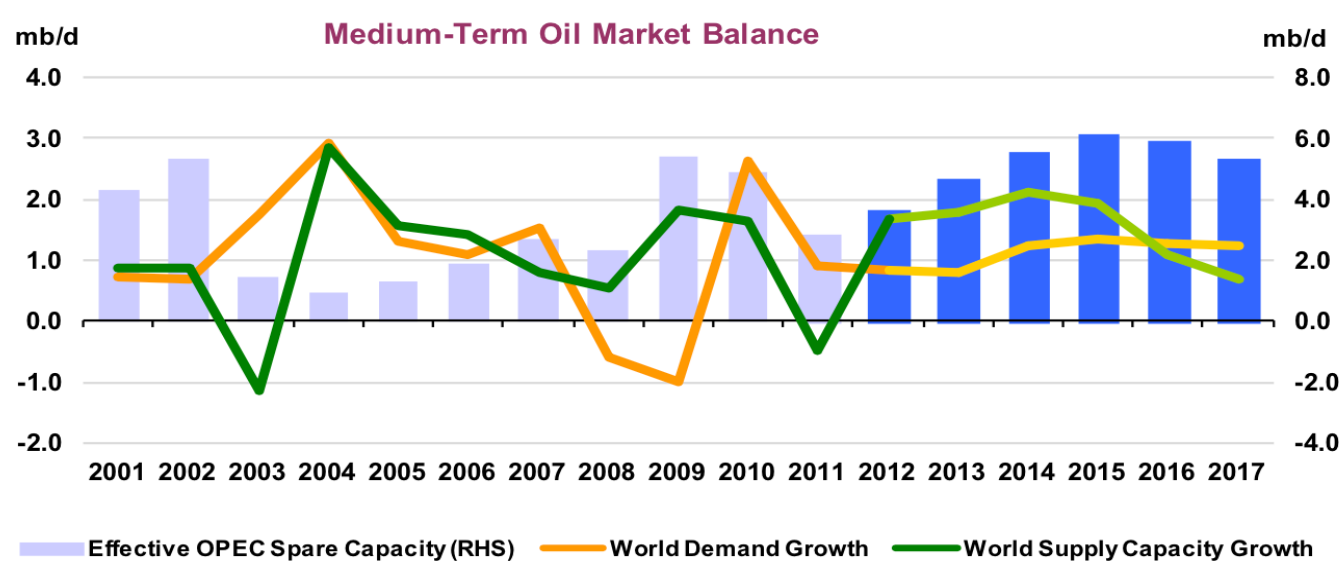

Figure 9: Global oil Supply and Demand Market shows the demand was lower than supply in 2009 and the supply will be more than demand by 2012. After 2012 is prediction. (World Energy Outlook, 2012)

Crude Oil Production in Yemen not obstructed by the crisis, the government with the companies continues oil production routinely; moreover, the government commenced a new Liquefied Natural Gas (LNG) plant in 2009 which reduce oil production due to technical reasons. On the other hand, oil and gas consumption has reduced slightly in 2009 by $11 \%$ comparing to 2008 and continue decline due to country instability.

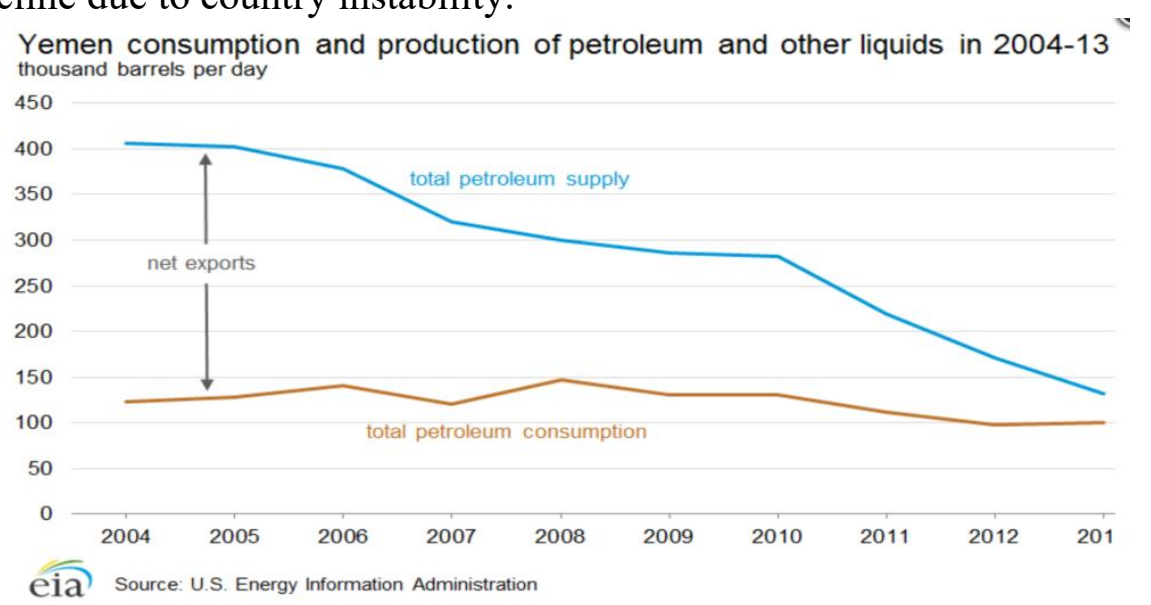

Figure 10: Yemen Crude Oil Production vs Oil consumption shows that in 2009 neither supply nor demand affected by the crisis. Note the production decline curve (Source IEA, 2012).

\section{Oil Market and Price}

During 2008 the oil price reach to its record high $(\$ 135 / \mathrm{bbl})$ which causes downturn in world demand and the oil price fall to $(\$ 40 / \mathrm{bbl})$, which makes financial market instability and the global recession began to spread. During 2009 and into 2010, the price of oil recovered some of this decline in the short period, based on help of economic expectation and long term market fundamentals to stay in a steady range $(\$ 65-\$ 85 / \mathrm{bbl})$ (IEA2010). 
The demand for crude oil is relatively inelastic demand where the $(\mathrm{E}<1)$ this means consumers not very responsive to price changes. ( $\mathrm{E}=\%$ change in quantity demanded $/ \%$ change in price) (Schiller, 2011).

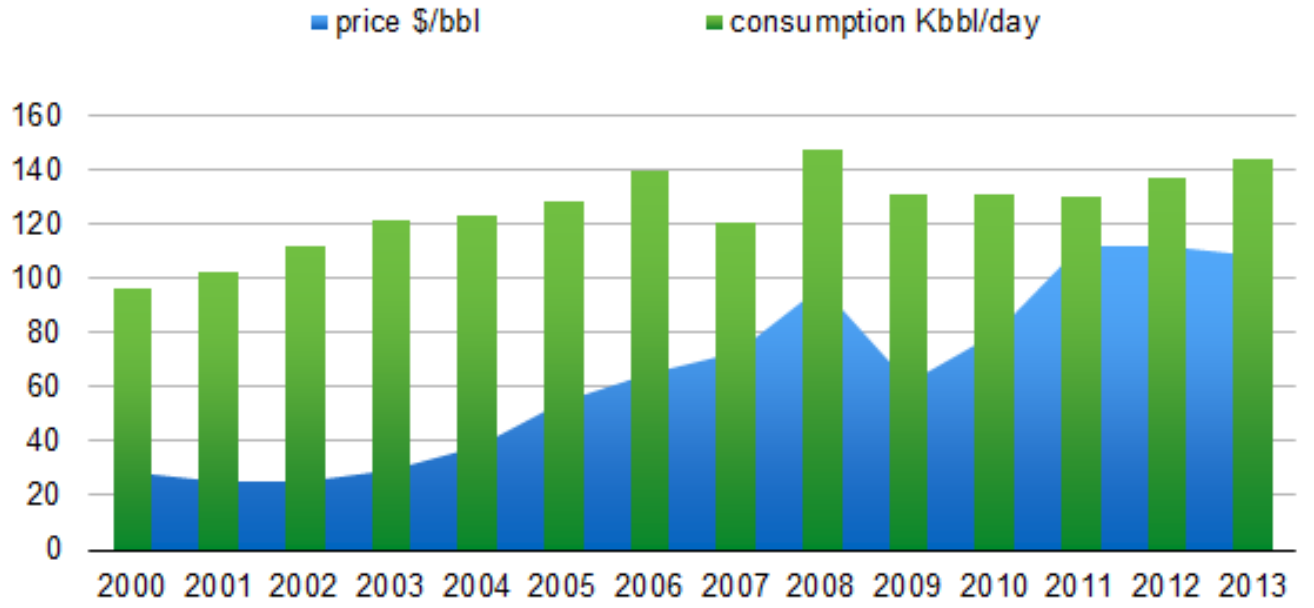

Figure 11: Crude Oil Average Export Price and consumption in Yemen shows no clear relationship between the crude price and consumption (Source: CSO).

\section{Oil Company Response}

Due to limited data available, oil companies in Yemen had a strong cash generation from the operation and being able to manage the crisis. Furthermore, most of them operate within a balanced budget and did not incur long-term debt after the crisis.

For instance, Calvalley Company in response to oil prices drops from 2008 to 2009, applied cost control rules during the crisis to maintain healthy balance sheet. Moreover, it was able to generate positive cash flow from operations enabled it to fund its capital program and to buy back 3.4 million shares with a low price and also acquire new assets in the Middle East as shown in the table below (Calvalley, 2012).

Table 1: Calvalley financial statement for the period (2006-2011) Note low share price in 2009 and the total asset increase in 2008 and 2009. (Source: Calvalley, 2012)

\begin{tabular}{lllllll}
\hline (\$000\$) & $\mathbf{2 0 0 6}$ & $\mathbf{2 0 0 7}$ & $\mathbf{2 0 0 8}$ & $\mathbf{2 0 0 9}$ & $\mathbf{2 0 1 0}$ & $\mathbf{2 0 1 1}$ \\
\hline Sales revenue, net of royalties & 30,053 & 46,520 & 46,264 & $\mathbf{3 1 , 3 5 4}$ & 39,494 & 46,170 \\
Fund flow from operation & 22,582 & 35,402 & 31,100 & $\mathbf{1 3 , 6 0 0}$ & 21,915 & 27,565 \\
Net Income (loss) & 15,506 & 23,300 & 19,161 & $\mathbf{2 , 9 5 1}$ & 10,941 & 21,343 \\
Working Capital & 72,300 & 75,100 & 75,800 & $\mathbf{7 0 , 7 0 5}$ & 69,683 & 75,356 \\
Total assets & 129,667 & 162,730 & 172,406 & $\mathbf{1 7 2 , 9 9 1}$ & 190,710 & 203,950 \\
Share price & $\mathbf{7}$ & $\mathbf{7 . 5}$ & $\mathbf{5}$ & $\mathbf{1 . 3}$ & $\mathbf{2 . 5}$ & $\mathbf{4 . 5}$ \\
\hline
\end{tabular}




\section{Section III Government and Agency Responses}

Government intervention in the term of Macroeconomic policy divided in monetary policy and fiscal policy where the government should manipulate both to overcome any economic crisis.

Naude (2009) emphasize that, there is no correct policy could be followed or implemented to eliminate and reduce the crisis impact. However, for the developing countries the responses should be divided into different phases: immediate, short term and long term policy responses directing to minimize the impact on the real economy and to support the financial systems and absorb the global changes (Naude, 2009).

\section{Monetary policy}

Monetary policy concerns with the system of the money supply and credit (Webster, 2003). Yemeni banks had a relative good liquidity due to the fair crisis impact CBY (2010). Monetary intervention by the Central Band of Yemen (CBY) represented in the following:

- The interest rate on local and foreign currency saving deposits was raised from $12 \%$ in 2009 to $20 \%$ in March 2010.

- CBY continued its intervention in the foreign exchange rate, aiming to reduce inflation and stabilized the exchange rate, to provide the market with the need of foreign currencies, however, the US Dollar increase to 219 Yemeni Rial in 2010 comparing to 200YR in 2008 (CBY, 2010).

\section{Fiscal Policy}

Fiscal policy by definition deals with government spending and taxation to control the economy (Webster, 2003). The government took a big burden in searching for alternative resource characterized by permanence through non-oil resources, development and renovation work on legislation to allow more investment to flow to the country. So several urgent meetings and declaration from financial and economic agencies during the first half of the fiscal year 2009 (MOF), to ensure a minimum level of financial integrity and fiscal discipline affect the state budget for the 2009 and 2010 as follows:

\section{(a) Short-term intervention:}

1. Reduce the government expenditure without compromising on social protection spending.

2. Spending restraint and alignment between the flow of resources and usage limits

3. Intensification of work for the collection of domestic revenues.

4. Follow-up spending for projects financed by external loans and grants.

\section{(b) Mid- term}

1. Preparation of economic studies and research that will help in the development of revenue and raise the outcome of the general resources of the country.

2. Preparation of technical statistics and the preparation of the necessary data related to revenue collection and other income resources.

3. Propose new laws and regulations or amend previous laws and regulations to be in line with the changes and development requirements.

(c) Long-term:

1. Encourage investment in mineral, agriculture, fisheries and tourism industries.

2. Start applying the treasury system and begin implementation of a medium-term expenditure framework.

3. Commence and start gas production from Yemen Gas project (YLNG) to compensate the reduction in revenues. 
4. Train workers in financial management and rehabilitation of appropriate fiscal and monetary rehabilitation.

\section{Policies Assessment:}

\section{(d) Monetary policy Assessment}

Monetary policy of money injection by CBY does not stable the exchange rate where it increase in 2010 by $8 \%$ comparing to 2008 , as a result, Yemen's national reserve decrease in 2010 by $45 \%$ comparing to 2008 . This solution may not work if the crisis last longer.

Increase the interest rate had good result where local currency saving deposits was raised by $11 \%$ in 2010 and Foreign currency deposits grew by $25 \%$ in 2010 against a growth of $16 \%$ in 2009 (CBY, 2011).

\section{(e) Fiscal policy Assessment}

- Government responses were limited to data gathering, improves money collection and conducts some studies. The proper strategic planning was missing.

- Yemen Gas project (YLNG) is a major project support the Yemen economy, but still nonrenewable resources and its harm the oil production (the ratio of oil decline rise by $10 \%$ due to gas production comparing previous years). (MOM)

- Stronger efforts will be needed to strengthen the non-oil resources also to improve the quality and the effectiveness of capital spending.

- Sustain Growth and achieve efficiency requires such higher level of financial intermediation than currently exists.

- There are no clear economical steps to maximize the benefit of oil resources or changing the strategy to improve the usage of this scary resource.

- Private business support and investment fortification is missing from government responses.

- The fair responses or 'laissez-faire' approach took by the government without a strategic planning will have a negative impact on the economic in the long term (Jones et al. 2009).

\section{Recommendation}

The Government should adopt a strategy to compensate the depleted oil and gas outcomes and shrinking of investment and relay on limited resources to improve the economy and prevent any negative impact in the future.

\section{(f) Monetary Policy}

The role of monetary policy need to be more strength to cope with external shocks in the future by including the following recommendation:

- Restructure the banking system and liberalization of public sector banks (Jones et al. 2009)

- The economic depends on dollar and conditions are not suitable for formal inflation targeting so the policy should focus on decrease inflation (MOF).

(g) Fiscal Policy

- Government should adopt the Fiscal Stimulus policy targeting AD increment such as increase government spending (long term) or/ and encourage more investment (Schiller 2011).

- The Government should have a stable long term economic growth without excessive attached to oil resources only (Schmitz, 2011).

- Expand the private sector's contribution to the diversification of the production base and the generation of more jobs (Salisbury, 2011).

IV. Attract more investment, accompanied by knowledge transfer and modern technology and the generation of value added to the national economy. (Jones et al. 2009) 


\section{(h) Supply-side policy}

This policy help to encourage work, produce, and invest in proper regulation condition aiming to increase or shift the aggregate supply (AS) curve right ward by:

- Strengthen the trade regime with the neighbors of the GCC countries and with overseas countries as a member of the World Trade Organization (WTO).

- Diversify the non-oil economic sectors in term of productive and exporting capacities such as the agricultural, minerals and industrial. (Ahmed, 2010)

- Encourage a sustain period of investment where it can be very beneficial for the economy in the long term Rodrik (1999; 2011).

\section{Conclusion}

The global crisis during 2008-2009 hit the Yemen economy as one of the developing countries, however it overcome the worst part of the crisis with sustain GDP growth and less effect in unemployment rate.

Statistical data and trend analysis for the period (2005-2013) used in this paper to highlight the impact of 2008 global crisis on the macroeconomic scale and Oil \& Gas industry. Yemen's economy in this period showed small degree of integration with the rest of the world with relatively high liquidity of foreign reserves to expand public spending.

Oil production and exporting is very crucial for Yemen's economy. However, Yemen has managed as well as oil surplus accumulated during the boom years of continuing to pursue an expansionary fiscal policy in the side of public spending.

This paper finds that the government responses were limited to gather statistics and improve revenue collection. The proper crisis management and strategic planning is missing from their responses. The oil companies survive and acquire new assets and credited shares with fewer prices due to strong operation cash flow.

Critical discussion and suggestion has provided to enhance the monetary and fiscal policies against any crisis or economic situation in the future.

The main recommendations from this paper are the following:

- Establish a strategy to achieve a stable long term economic growth without excessive attached to oil resources only.

- Expand the private sector's contribution to the diversification of the production base and increase job opportunities.

- The Private sector is the key to promoting sustain non-hydrocarbon growth (Schmitz, 2011).

- Attract investment, accompanied by knowledge transfer and modern technology and the generation of value added to the national economy (Jones et al. 2009).

\section{References}

[1] Ahmed, M. M. (2010). Global Financial Crisis Discussion Series Paper 19: Sudan Phase 2. Overseas Development Institute, London, UK.

[2] Breisinger, C., Diao, X., Collion, M. H., \& Rondot, P. (2011). Impacts of the triple global crisis on growth and poverty: the case of Yemen. Development Policy Review, 29(2), 155-184.

[3] Calvalley Annual Reports. (2012). Available from: http://www.calvalleypetroleum.com/pages/investors/financial-reports/annualreports.cfm [Accessed: 13rd March 2015]. 
[4] CBY (Central Band of Yemen). (2008). Annual Report 2008. Available from: http://www.centralbank.gov.ye/newslettar.aspx?keyid=47\&pid=46\&lang=1\&cattype= 6. [Accessed: 13rd March 2015].

[5] CBY (Central Band of Yemen). (2009). Annual Report 2009. Available from: http://www.centralbank.gov.ye/newslettar.aspx?keyid=47\&pid=46\&lang=1\&cattype $=$ 6. [Accessed: 13rd March 2015].

[6] CBY (Central Band of Yemen). (2010). Annual Report 2010. Available from:Yemen.http://www.centralbank.gov.ye/newslettar.aspx?keyid=47\&pid=46\&lang $=1 \&$ cattype $=6$. [Accessed: 13rd March 2015].

[7] CBY (Central Band of Yemen). (2011). Annual Report 2011.Available from: http://www.centralbank.gov.ye/newslettar.aspx?keyid=47\&pid=46\&lang=1\&cattype= 6. [Accessed: 13rd March 2015].

[8] CBY (Central Band of Yemen). (2012). Annual Report 2012. Available from: http://www.centralbank.gov.ye/newslettar.aspx?keyid=47\&pid=46\&lang=1\&cattype $=6$. [Accessed: 13rd March 2015].

[9] Claessens, S., \& Kose, M. A. (2010). The financial crisis of 2008-2009: Origins, issues, and prospects. Journal of Asian Economics, 21(3), 239-241.

[10] CSO (Central Statistics Organization). (2007). HBS 2005/2006. Household budget survey $2005 / 2006$.

[11] CSO (Central Statistics Organization). (2008). Statistical yearbook Yemen 2008. Available from: $h t t p: / / w w w . c s o-$ yemen.org/content.php? lng $=$ english \&pcat $=131$. [Accessed: 13rd March 2015].

[12] CSO (Central Statistics Organization). (2009). Statistical yearbook Yemen 2009. Available from:

[13] http://www.cso-yemen.org/content.php?lng=english\&pcat=131. [Accessed: 13rd March 2015].

[14] CSO (Central Statistics Organization). (2010). Statistical yearbook Yemen 2010.Available from:

[15] http://www.cso-yemen.org/content.php?lng=english\&pcat=131. [Accessed: 13rd March 2015].

[16] CSO (Central Statistics Organization). (2011). Statistical yearbook Yemen 2011.Available from:

[17] http://www.cso-yemen.org/content.php?lng=english\&pcat=131. [Accessed: 13rd March 2015].

[18] CSO (Central Statistics Organization). (2012). Statistical yearbook Yemen 2012.Available from:

[19] http://www.cso-yemen.org/content.php?lng=english\&pcat=131. [Accessed: 13rd March 2015].

[20] CSO (Central Statistics Organization). (2013). Statistical yearbook Yemen 2013. Available from:

[21] http://www.cso-yemen.org/content.php?lng=english\&pcat=131. [Accessed: 13rd March 2015].

[22] Dutt, A. K. (2006). Aggregate demand, aggregate supply and economic growth. International Review of Applied Economics, 20(3), 319-336.

[23] Economic Online. Available from: http://www.economicsonline.co.uk. [Accessed: 3rd March 2015].

[24] Frisch, H. (1983). Theories of inflation. Cambridge University Press. 
[25] Gale, W. G., \& Orszag, P. R. (2003). Economic effects of sustained budget deficits. National Tax Journal, 463-485.

[26] Headey, D., \& Fan, S. (2008). Anatomy of a crisis: the causes and consequences of surging food prices. Agricultural Economics, 39(s1), 375-391.

[27] Hossain, N. (2010). The Social Impacts of Crisis: Findings from community-level research in five developing countries. Available at SSRN 1879128.

[28] IEA (International Energy Agency), Available from: http://www.iea.org/statistics/statisticssearch/report/? country $=$ YEMEN\&product $=$ oil\&year=2010, [Accessed: 8rd March 2015].

[29] IMF (International Monetary Fund). 2008. Country Report 07/334 September 2007

[30] IMF (International Monetary Fund). 2009. Country Report 09/100 March 2009.

[31] IMF (International Monetary Fund). 2009a. Staff country report 2009. Yemen. Washington, D.C.: International Monetary Fund.

[32] IMF (International Monetary Fund). 2010. Country Report 10/300 September 2010.

[33] Jones, N., C. Harper, S. Pantuliano, S. Pavanello, K. Kyunghoon, S. Mitra, K. Chalcraft (2009), "Impact of the Economic Crisis and Food and Fuel Price Volatility on Children and Women in the MENA Region", Working Paper No. 310, ODI and UNICEF, November Available from: (http://www.odi.org.uk/resources/download/4422-working-paper-310.pdf).

[34] Keynes, J. M. (2006). General theory of employment, interest and money. Atlantic Publishers \& Dist.

[35] Krishna, A., \& Skott, P. (2005). Keynesian Theory and the AD-AS Framework: A Reconsideration.

[36] Marshalle, M. I. (Ed.). (2006). Economics of unemployment. Nova Publishers.

[37] MOM (Ministry of Oil and Gas Yemen). Available from: http://www.mom.gov.ye/en/ [Accessed: 23rd March 2015].

[38] MOIT (Ministry of Industry and Trade). Available from: http://www.moit.gov.ye/moit/ [Accessed: 2nd March 2015].

[39] MOF (Ministry of Finance). Available from: http://www.mof.gov.ye [Accessed: 8rd March 2015].

[40] Naudé, W. (2009). The financial crisis of 2008 and the developing countries (No. 2009/01). WIDER Discussion Papers, World Institute for Development Economics (UNU-WIDER).

[41] Rodrik, Dani. 1999. The New Global Economy and Developing Countries: Making Openness Work. Washington, D.C.: Overseas Development Council

[42] Rodrik, Dani. 2011. The Globalization Paradox: Democracy and the Future of the World Economy. New York: W.W. Norton and Co.

[43] Salisbury, P. (2011). Yemen's Economy: Oil, Imports and Elites. Middle East and North Africa Programme Paper MENA, 2011.

[44] Schiller, B. R. (2011). The macro economy today. Tata McGraw-Hill Education.

[45] Schmitz, C., (2011) Crisis in the Yemeni Economy: A Troubled Transition to PostHydrocarbon Growth. Middle East Institute, Article // Nov. 15, 2011

[46] Toronto Stock Exchange. Available from: https://ca.finance.yahoo.com/q? $s=C V I$ A.TO. [Accessed: 10th March 2015]

[47] Webster, T. J. (2003). Managerial economics: theory and practice. Elsevier.

[48] World Bank. 2007. Poverty assessment report. Yemen. Washington, D.C.: World Bank. 
[49] World Bank. 2008. Lessons from World Bank research on financial crises. Policy research working paper No. WPS 4779. Washington, D.C.: World Bank.

[50] World Bank. 2009a. World development indicators. Washington, D.C.: World Bank.

[51] World Bank . 2009d. The impacts of the food crisis on poverty in Yemen. Mimeo. Washington, D.C.: World Bank.

[52] World Bank (2009g) 'Country Brief: Yemen'. Washington, DC: World Bank

[53] World Bank (2010). International Finance Corporation. 2010. Yemen Country Profile: Enterprise Surveys.

[54] World Energy Outlook (2012). Energy Information Administration, US Department of Energy. Available from: http://www.worldenergyoutlook.org/.[Accessed: 20th March, 2015].

[55] YLNG (Yemen LNG). Available from: http://www.yemenlng.com/ws/en/home.aspx [Accessed: 23rd March 2015]. 